\title{
Phytochemical Analysis of Plant Resources having Antimicrobial Properties Obtained from Aravali Hills of Rajasthan, India
}

\author{
Sudha Babel*, Rupali Gupta and Latika Sachihar \\ Department of Textiles \& Apparel Designing, College of Home Science, MPUAT, \\ Udaipur, India \\ *Corresponding author
}

\section{A B S T R A C T}

Keywords

Antimicrobial properties,

Antimicrobial activity,

Phyo chemical analysis

Article Info

Accepted:

10 February 2018

Available Online:

10 March 2018
Medicinal plants have age long remedies for human diseases because they contain components of curative value. An increasing interest in herbal remedies is observed in several parts of India and many of the herbal remedies are incorporated into traditional medicinal plant practice. In the present study questions related diseases that have been managed traditionally using medicinal plant were asked by sixty respondents. Collected data were analysed. The study reports the plant sources used by rural women to cure the various diseases and phytochemical analysis plant sources used by the women. On the basis of the study it can be concluded that these plant resources may serve as a potential source for wet finish application on the textiles for treatment of skin wounds, antifungal, anti-microbial finish, hence further research should be conducted in order to explore their applications.

\section{Introduction}

According to World Health Organization (WHO) more than $80 \%$ of the world's population relies on traditional medicine for their primary healthcare needs. Use of herbal medicines in Asia represents a long history of human interactions with the environment. Plants used in traditional medicine contain a wide range of ingredients that can be used to treat chronic as well as infectious diseases. A vast knowledge of how to use the plants against different illnesses may be expected to have accumulated in areas where the use of plants is still of great importance (Diallo et al., 1999). The medicinal value of plants lies in some chemical substances that produce a definite physiological action on the human body. The most important of these bioactive compounds of plants are alkaloids, flavonoids, tannins and phenolic compounds (Edeoga et al., 2005). Developing countries like India depend on plant resources mainly for herbal medicines, food, forage, construction of dwellings, making household implements, sleeping mats, and for fire and shade.

The use of medicinal plants as traditional medicines is well known in rural areas of many developing countries (Sandhu and Heinrich, 2005; Gupta et al., 2005). Traditional healers claim that their medicine is cheaper, more effective and impart least side effects as compared to synthetic medicines. In 
developing countries, low-income people such as farmers, people of small isolate villages and native communities use folk medicine for the treatment of common infections (Rojas et al., 2006). For millennia, the Indian population has depended upon mostly plant based crude drugs for the treatment of variety of human ailments. India has about 18,000 species of angiosperms, of with about 2,500 species are considered as important source of medicinal and aromatic chemical components in modern medicine also, plants occupy a very significant place as raw material for some important drugs.

Undulating hills of Aravali, supporting the dry deciduous forests, provide an unimaginable beautiful ambience. The area is characteristically rich in floral diversityparticularly medicinal plants. It has numerous floral and faunal species of global conservation significance. The rare flora comprises Kadaya (giving medicinal gum), Gugal, amla and Moosli etc. The predominant trees are- Khair, Salai, Modad, Dhavada, Khakhara, Timru. During late winters (February-March) Khakhara-the flame of the forests- known by many different names such as- Palash, Tesu, Kesudo, Dhak etc. is generally in bloom with its striking red colour resembling flames in the forests rajasthantrekking.com/thearavalis.htm

In general, these plants are used in folk medicine in the treatment of skin diseases, venereal diseases, respiratory problems and nervous disorders. There is lack of scientific studies on these selected plants. Screening of medicinal plants for antimicrobial activities are important for finding potential new antimicrobial finishes for textiles. This paper based on results of survey conducted in Udaipur where the questions about plant sources used for curing the diseases were asked, on the basis of results this paper reports documentation of Plant Resources having
Antimicrobial Properties and the phytochemical analysis for different plant extracts.

\section{Phyto-chemical screening of plant sources}

The identified plant sources of the region were subjected to phyto-chemical analysis for screening of plant sources for their antimicrobial properties.

\section{Materials and methods for phyto-chemical screening of plant sources}

\section{Selection of the plant sources}

The leaves of ten plant sources were collected in around operational villages which were washed with distil water, shade dried and powdered.

\section{Solvents used in extraction procedures}

Ethanol, Methanol, Chloroform, Acetone and distil water.

\section{Preparation of plant extract by aqueous} decoctions

20 gms of dry leaf powder of selected plant sources was boiled in $100 \mathrm{ml}$ distilled water for 15 minutes, it was allowed to cool and then filtered. The filtrate was used as the aqueous decoctions.

The leaf extracts of eleven plant sources were analyzed for the presence of flavonoids, alkaloids, phenols, saponins, terpenoid and tannins according to standard methods.

\section{Alkaloids [Mayer's test] \\ $1.36 \mathrm{gm}$ of mercuric chloride dissolved in $60 \mathrm{ml}$ and $5 \mathrm{gm}$ of potassium iodide were dissolved in $10 \mathrm{ml}$ of distilled water respectively. These two solvents were mixed}


and diluted to $100 \mathrm{ml}$ using distilled water. To one $\mathrm{ml}$ of acidic aqueous solution of samples few drops of reagent was added. Formation of white or pare precipitate showed the presence of alkaloids.

\section{Flavonoids}

In a test tube containing $0.5 \mathrm{ml}$ of extract of the samples, 5 to10 drops of diluted HCI and small amount of $\mathrm{Zn}$ and $\mathrm{Mg}$ were added and the solution was boiled for few minutes. Appearance of reddish pink or dirty brown colour indicated the presence of flavonoids.

\section{Saponins}

A drop of sodium bi-carbonate was added in a test tube containing about $50 \mathrm{ml}$ of an aqueous extract of sample. The mixture was shaken vigorously and kept for $3 \mathrm{~min}$. A honey comb like froth was formed and it showed the presence of saponins.

\section{Phenols [Ferric chloride test]}

To $1 \mathrm{ml}$ of alcoholic solution of sample, $2 \mathrm{ml}$ of distilled/water followed by a few drops of $10 \%$ aqueous ferric chloride solution were added. Formation of blue or green colour indicated the presence of phenols.

\section{Tanins [Lead acetate test]}

In a test tube containing about $5 \mathrm{ml}$ of an aqueous extract, a few drops of $1 \%$ solution of lead acetate was added. Formation of a yellow or red precipitate indicated the presence of tannins.

\section{$\mathrm{FeCl}_{3}$ test}

A $2 \mathrm{ml}$ filtrate [200mg of plant material in $10 \mathrm{ml}$ distilled water, filtered], and $2 \mathrm{ml}$ of $\mathrm{FeCI} 3$ were mixed. A blue or black precipitate indicated the presence of tannins

\section{Terpenoid}

$2 \mathrm{ml}$ of chloroform and $1 \mathrm{ml}$ of concentrated $\mathrm{H}_{2} \mathrm{SO}_{4}$ was added to $1 \mathrm{mg}$ of extract and observed for reddish brown colour that indicated the presence of terpenoid.

\section{Results and Discussion}

\section{Phyto-chemical screening of plant sources}

The identified plant sources of the region were subjected to phyto-chemical analysis for screening of plant sources for their antimicrobial properties.

The results of the phytochemical screening in Table 1 indicated the presence of Alkaloids, glycosides, saponin, phenols, steroids etc. The presence of these secondary metabolites has contributed to its medicinal value as well as physiological activity. For instance Flavonoids have been referred to as nature's biological response modifiers, because of their inherent ability to modify the body's reaction to allergies and virus and they showed their antiallergic, anti-inflammatory, anti-microbial and anti-cancer activities. The positive effects of glycoside and cardiac glycoside are not common but their toxic effects include decreased heart rate, sympathetic activity and systematic vascular resistance. The presence of some of these anti nutrients can be reduced by various processing technique. Plant steroids possess insecticidal and antimicrobial properties. They are also used in nutrition, herbal medicine and cosmetics.

Tannins were reported to exhibit antiviral, antibacterial and anti-tumour activities. It was also reported that certain tannins were also used as diuretic. Tannins can be used as an anti-bacterial because it has phenon group, so tannin have properties like alcohol, an antiseptic that can be used as antimicrobial component. 
Table.1 Phyto-chemical screening of plant sources

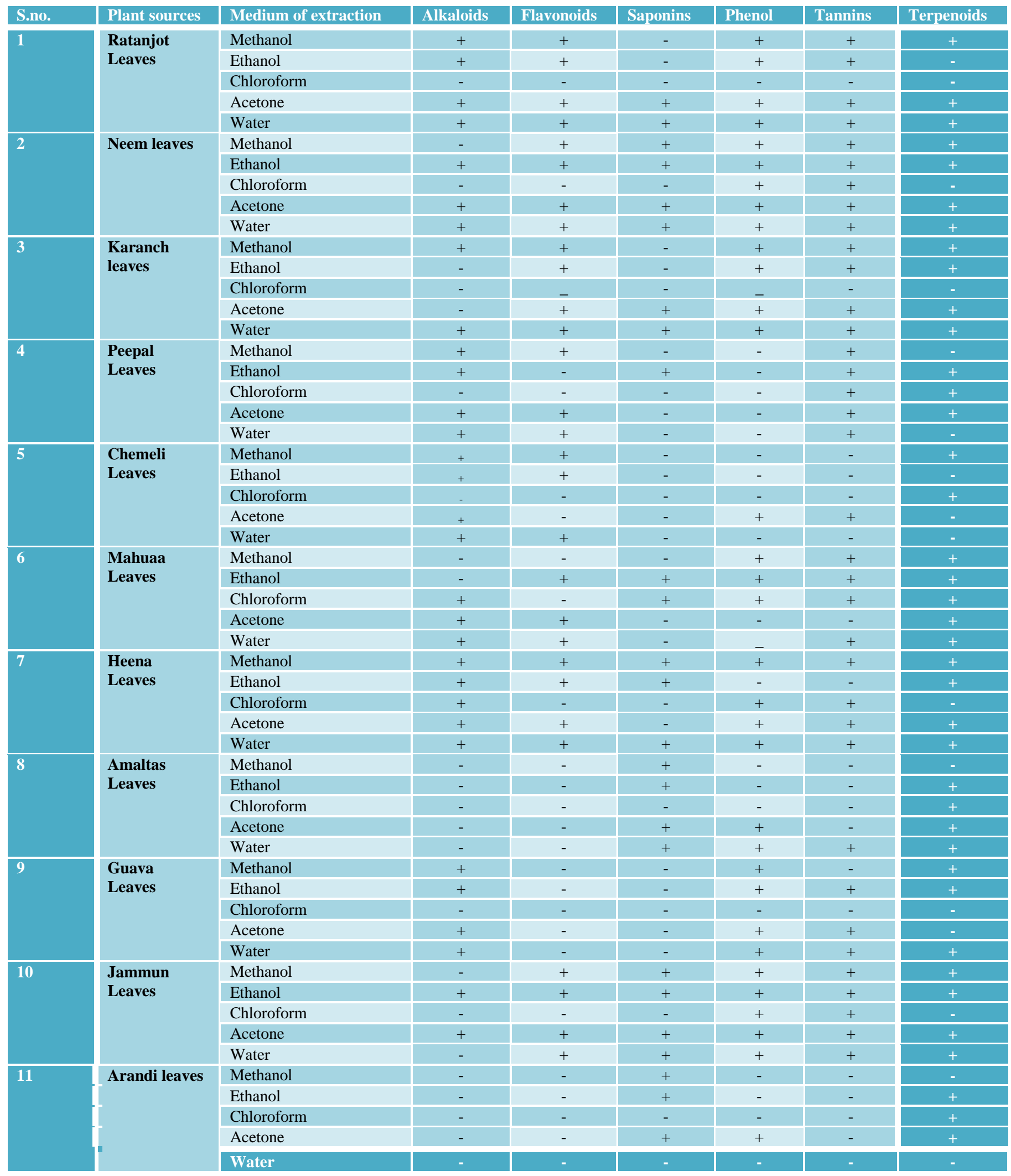


Saponin is used as mild detergents. It is also used to allow antibody access in intracellular proteins. In medicine, it is used in hypercholesterolemia, hyperglycaemia, antioxidant, anticancer, antifungal, antiinflammatory, weight loss, etc.

From the present study, it can be assumed that these leaves may serve as a potential application for treatment of skin wounds, antioxidant, antifungal, anti-allergic, antiinflammatory, anti-microbial etc, The results obtained from phyto chemical revealed that the plants contained bioactive agents which are connected with antimicrobial properties in plants. These agents are alkaloids, saponins, flavonoids and tannins. Further research is needed to find out the uses of these extracts for the application of antimicrobial finishes on the textiles.

\section{References}

Erdogrul OT (2002). Antibacterial activities of some plant extracts used in folk medicine. Pharmaceutical Biol. 40:269-273.

Hewitt W, Vincent S (1989). In: Theory and application of microbiological assay. Academic Press, San Diego, p. 39.

http://www.rajasthantrekking.com/ Trekking in Rajasthan, India

Jain A, Katewa SS and Galav PK, (2005). Some phyto therapeutic claims by tribals of southern Rajasthan, Indian $J$ Traditional Knowledge, 4 (3) 291.

Jain SK, (1975). Medicinal plants, $2^{\text {nd }}$ edn, (National Book Trust of India, New Delhi),

Katewa SS and Arora A, (1997) Some plants of folk medicine of Udaipur district, Rajasthan, Ethnobotany, 948.

Katewa SS, Chaudhary BL, Jain A and Galav PK, (2003) Traditional uses of plant biodiversity from Aravalli hills of Rajasthan, Indian $J$ Traditional Knowledge, 21.

Nostro A, Germano MP, D'Angelo V, Marino A, Cannatelli MA (2000). Extraction methods and bioautography for evaluation of medicinal plant antimicrobial activity. Lett. Appl. Microbiol. 30(5): 379.

Rojas JJ, Ochoa VJ, Ocampo SA, Muñoz JF (2006). Screening for antimicrobial activity of ten medicinal plants used in Colombian folkloric medicine: A possible alternative in the treatment of non-nosocomial infections. BMC Complementary and Alternative Medicine. 6:2.

Sebastian MK and Bhandari MM, (1984) Medicinal plant lore of Udaipur district Rajasthan, Bull Med Ethnobot Res, 5 (34) 133.

Singh V and Panday RP, (1980) Medicinal plant lore of the tribals of eastern Rajasthan, J Econ Tax Bot, 1137.

\section{How to cite this article:}

Sudha Babel, Rupali Gupta and Latika Sachihar. 2018. Phytochemical Analysis of Plant Resources having Antimicrobial Properties Obtained from Aravali Hills of Rajasthan, India. Int.J.Curr.Microbiol.App.Sci. 7(03): 1121-1125. doi: https://doi.org/10.20546/ijcmas.2018.703.133 